\title{
Two orthogonal models: an opinion
}

Keywords: Christianity, middle east, voyeurism, Islam Opinion

Christianity is a fascinating phenomenon. One of its primary characteristics is its continuity. One cannot comprehend Christianity - what it is, what it means and what its proponents really refer to - without comprehending this continuity, with all its broadest ramifications. Continuity does not refer to a "level of belief" in the system called Christianity- for at time of this writing, Christianity is at an all-time nadir in its 'home territory' of Europe. Belief has never been as low (weak) as it is today. Thousands of Church-buildings have and are being converted to other uses, including Mosques. The nadir has a reason; the populace awakens and is not 'happy' with what they see. It is not the purpose of this writing or this writer to opine to correctness of this view. As in any difficult-to-understand concept, conceptual models can be very helpful aids to understanding. In this case, one single model is too basic. Here are two models orthogonal to one another, ${ }^{1}$ that somewhat explain the vast cultural difference between "the West" and "the Middle East" as they presently exist. In this case, the idea of "West" includes all of the so-called western countries, but particularly the European Christian culture. While "Middle East" refers to Islam - as opposed to the entire east, that is, this does not refer to China ("far east") nor to India, nor to any of their derivative cultures (e.g., Japan). As any model, this is a simplification, perhaps an 'over' simplification, but that is the nature of what a model does, it simplifies to facilitate comprehension.

M1: "In the west, now is history, in the east, history is now."

M2: "In the west, power is the tool to acquire wealth; in the East, wealth is the tool to acquire power."

\section{Model \# I}

In the West, everything is based on "now-ism". On the feeling that "now" is the only thing that really matters - instant satisfaction, instant gratification - "I can't get no..." the old song; that symbolizes all of the culture that places the "movie star" or the sports star at the epitome of civilization. Now is what matters. Everything previous to now is history, and history is old, of little consequence to everything that is modern. Youth counts; 'old ones' time has passed and they are passé. Now is Now, and one second ago, previous instant is noninstant gratification, is pre-now, history.

The present is always in a process of becoming the past - and the past is passé, because it has already occurred. Get with the now. That is why journalism has become a part of the entertainment industry, while "past" is depicted as "conjuring up the past" - an exercise somewhat akin to fantasy. Voyeurism has gone wild. In the East, history is everything; it is here with us, it is now. Everything has a history and this history is terribly relevant to what we all do, at all times (yes, with 'both' meanings of "terrible"). Look at Japan, China and India. Everything they think, say and do is based upon a long-term view of history and how actions affect the way history unfolds. Withal, they are barely recognizing the power of the historical now. History is an 'Orthogonal: similar to perpendicular; intersecting, laying at right angles to one another; preserving length and distance; statistically independent
Volume 4 Issue 2 - 2019

\author{
Mordechai Ben Menachem \\ Yeshiva Kever Rachel, Israel
}

Correspondence: Mordechai Ben Menachem, Yeshiva Kever Rachel, Israel, Email quality@acm.org

Received: February 15, 2019 | Published: April 18, 2019

important aspect of how they view the world. It is 'an aspect'.

Islam ties 'Now' into everything done. Islamists tie their 'Now' into all their public speeches. Anyone listening to them, who does not understand the 'Now', cannot understand what they are really saying to their audience. When the Imam tells them what Mohammed did, the purpose is to tell them what they are to do - now! An Imam giving a sermon, does not state that the tree or the rock will scream "there is a Jew behind me, come and kill him" trivially. He knows his audience understands this to mean that they are to go out and actually listen to the trees and the rock - NOW! And they actually do listen. I have seen fathers instructing their sons to listen carefully to the rocks. This isn't mysticism (well, it is, but not in the Western sense). This is "History is Now," except that this happens to be history that has yet to occur, and that is also fine, because history need not be the uni-directional vector that Western Philosophical thought claims it to be.

\section{Model \#2}

To the western mind, power is a tool to acquire wealth (one of many, but the most important one). Wealth is the goal: "if you're so smart, why aren't you rich" ${ }^{2}$ is consummate western thinking. The expression would be incomprehensible in any Middle Eastern language. Wealth is the ultimate goal of what one does; just as the most 'practical' question to a new acquaintance is 'what do you do' - meaning what you do for creating and attaining wealth, rather than who you are, there is what you are. You can be the son of a criminal, who acquired his wealth by illegitimate means, but by having passed it on to the next generation it is "cleansed" and that generation is simply wealthy, which is blessed.

In the East, money is a tool to acquire power (one of many, the most important). Power is the goal. ${ }^{3}$ One acquires, gathers and maintains power, and many (almost any) means towards this goal are legitimate. Power, particularly great power, is meant to be passed on from one generation to another - passing the knife among the Bedouin, from the Sheik to his brother or favourite son, not necessarily the eldest or the most obvious heir. In the Middle East everything said has three layers: The visible layer is content, what was said, the middle layer is what was really meant and the lowest what is hidden. When hearing words, one attempts to penetrate the layers, to understand the real intention and what is hidden. In the Middle East, there is no forgetting and no forgiving. Time has nothing to do with this. There is only waiting; ${ }^{2}$ By the way, statistically, there is no correlation between the two. People are rich who have a low IQ; people with a high IQ can be poor.

${ }^{3} \mathrm{O}^{\prime}$ Rourke PJ. Eat the Rich: a Treatise on Economics. Atlantic Monthly Press; 1998. 
and revenge. Abdullah II, the present king of Jordan, inherited Hussein Bin-Talal, ${ }^{4}$ completely contrary to expectations; all 'analysts' expected the kingdom to be passed to Hussein's brother, who was Crown Prince and is now nobody. Westerners do not understand that poverty has nothing whatever to do with terrorism, because wealth is neither the goal nor the issue. Therefore, pumping money into regimes or places to improve the standard of living has no effect on reducing terror, because the issues are simply unrelated. (It has nothing to do with the standard of living either, because none of it ever gets to those for whom it matters. Western handouts remain with the ruling family, always!) It is like giving shoe polish to people who prefer to habitually go barefoot - it might be a nice, generous thing to do, but it simply does not matter. ${ }^{1,2}$

Terror is a tool for acquisition of power, not for wealth creation. The people of a country are "better off" or less so, it is of no real interest, to anyone. Richer people do not have a "vested interest" in calm because wealth (read: standard of living) is not an issue of real consequence. It is an issue of convenience. Actually, the very idea that terrorism is a result of poverty is ludicrous. Arabs are fantastically wealthy, it just has not been spread efficiently and this does not particularly bother; mostly, quite the opposite, an average "Arab in the street," is proud that the ruler is rich. Bin Laden did not say that the Saud family is to be assaulted for its acquisition of wealth, or because they have not shared it with their subjects. Neither of these ideas would be considered normal; nor would spreading it be considered even desirable. The Saud family is to be assaulted because they have allowed the infidel into the Holy Land of Islam, into Hajaj and allowed him to share in the oil wealth, which allows the infidel to better resist Jihad. In the Arab world, there is a time-honoured tool called terrorism. This is the modern name, in other times it has been called other things. This

${ }^{4}$ Hussein's grandfather was Abdallah, who was the king of Jordan before him (his father was insane and died in an asylum). is not new. It was used, very effectively, against the Crusaders and that is indeed, their action model; then, it was called assassination. ${ }^{5}$ (The word derives from 'a user of Hashish'.) They never cease to discuss this - History is Now. This is a basic part of the rhetoric, at almost a daily level of repetition. Yes, that is correct; the subject of the crusades is daily conversation. This is totally contrary to western concepts of the relevance of history. Additional money (availability) increases terror because it provides more resources for pursuit of power. Terror is the tactic; Authority is the strategy; Money the means; Power is the goal. In this case, money is a double-tool. Acquisition of money accrues power, while taking money from the West weakens it, in the area where they are most vulnerable; as they desire it for itself, this, itself is the west's weakness. You now understand what the differences are between the culture that is Christianity (Europe and its derivatives) "Now is History!" and the culture that is Islam (the Middle East and its derivatives) "History is Now!

\section{Acknowledgments}

None.

\section{Conflicts of interest}

Author declares that there is no conflict of interest.

\section{References}

1. Duggan Alfred. The Story of the Crusades, 1097-1291. Faber and Faber; 1963. p. 152.

2. ORourke PJ. Eat the Rich: a Treatise on Economics. Atlantic Monthly Press; 1998.

${ }^{5}$ Duggan Alfred. The Story of the Crusades, 1097-1291. Faber and Faber; 1963; p. 152. 